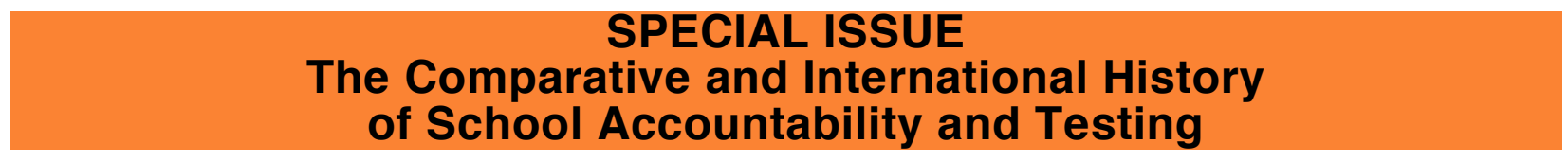

\title{
education policy analysis archives
}

A peer-reviewed, independent, open access, multilingual journal

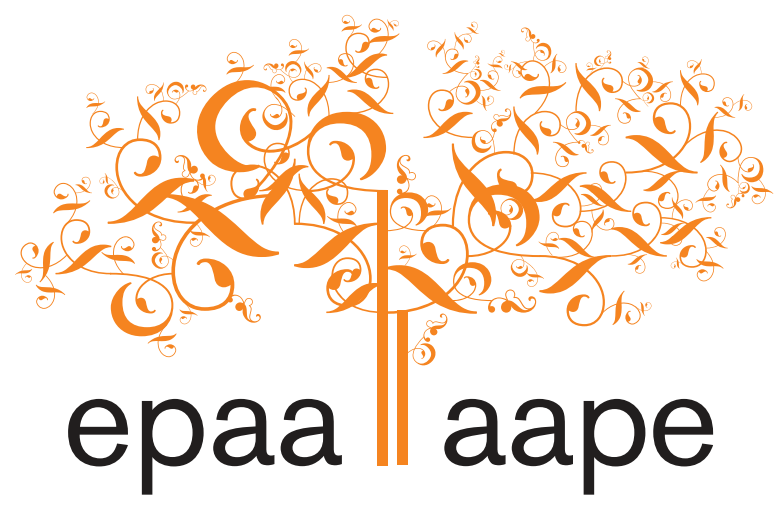

Arizona State University

\section{The Development of Educational Accountability in China and Denmark}

\author{
Palle Rasmussen \\ Aalborg University \\ Denmark \\ ¿ro \\ Yibuan Zou \\ Central China Normal University \\ China
}

Citation: Rasmussen, P., \& Zou, Y. (2014). The development of educational accountability in China and Denmark. Education Policy Analysis Archives, 22(121). http://dx.doi.org/10.14507/epaa.v22.1693. This article is part of EPAA/AAPE's Special Issue on The Comparative and International History of School Accountability and Testing, Guest Co-Edited by Dr. Sherman Dorn and Dr. Christian Ydesen.

\begin{abstract}
In recent decades, the concept of accountability has attracted more and more attention in public governance and management. The management of education is no exception. This article presents and discusses the evolution and current status of educational accountability in two different national contexts, China and Denmark. Two main sectors of education are covered, general school education and higher education. It is shown that both countries are marked by an increasing concern with educational accountability, that differences in history and culture between the two countries are reflected in the approaches to accountability, but that there are still considerable similarities in the types of accountability pursued. Under the
\end{abstract}


influence of a transnational regime of policy development both countries seem to be moving towards output-based accountability, but more traditional inspection continues to have a role. Keywords: educational accountability; China; Denmark; school education; higher education

E1 desarrollo de los modelos de rendición de cuentas educativas en China y Dinamarca. Resumen: En las últimas décadas, el concepto de rendición de cuentas ha atraído cada vez más atención en la gobernanza y la gestión pública. La gestión de la educación no es una excepción. Este artículo presenta y analiza la evolución y el estado actual de los modelos de responsabilidad educativa en dos contextos nacionales diferentes, China y Dinamarca. Dos sectores claves de la educación son analizados, la educación general y la educación superior. Se muestra que ambos países están marcados por una creciente preocupación con los modelos de responsabilidad educativa, que las diferencias en la historia y la cultura entre los dos países se reflejan en los enfoques, pero que todavía hay considerables semejanzas en los tipos de rendición de cuentas que se utilizan. Bajo la influencia de un régimen transnacional de desarrollo de las políticas de ambos países parecen estar moviéndose hacia los modelos de responsabilidad educativa basados en resultados, pero una inspección más tradicional sigue teniendo un papel.

Palabras clave: los modelos de responsabilidad educativa; China; Dinamarca; educación escolar; educación superior

\section{Desenvolvendo modelos de responsabilização educacional na China e Dinamarca.}

Resumo: Nas últimas décadas, o conceito de responsabilização educacional tem atraído cada vez mais atenção nas áreas de governança e gestão pública. A gestão da educação não é exceção. Este artigo apresenta e analisa a evolução e situação atual dos modelos de responsabilização educacional em dois contextos nacionais diferentes, China e Dinamarca. São analisados dois áreas principais da educação, o ensino geral e o ensino superior. Nosso analise mostra que ambos países são marcados por uma crescente preocupação com modelos de responsabilização educacional, as diferenças de história e cultura entre os dois países são refletidas nas abordagens, mas ainda há semelhanças significativas nos modelos de responsabilização educacional utilizados. Sob a influência de um sistema transnacional de desenvolvimento de políticas em ambos os países parecem estar se movendo em direção a modelos de responsabilização educacional com base nos resultados, mas uma inspeção mais tradicional ainda tem um papel.

Palavras-chave: modelos de responsabilização educacional; China; Dinamarca; educação escolar; ensino superior

\section{Introduction}

Accountability is about the request for responsibility and giving account for that responsibility. It involves a social relationship between at least two parties of which one is in a position to request or demand accounting from the other for certain actions. During the last three decades the concept of accountability has come to be used much more; a scanning of digitally available texts shows that compared to 1960 the word 'accountability' was used roughly 5 times as often in 1980 and roughly 10 times as often in 2000 (Dubnick, 2012, p. 2). One of the main reasons for this is that the concept has been taken up in public governance and management, including the management of educational processes and institutions.

In this paper we will discuss the evolution and current status of educational accountability in two nations, China and Denmark. In size, history and culture these are two very different nations, but both are influenced by global trends in educational thought and policy, including the focus on 
accountability. The analysis has a double aim. We try to uncover the character of educational accountability in its specific contexts in order to differentiate the concept of accountability. But we also try to identify common elements and trends of educational accountability in these two very different contexts in order to identify common impacts from global forces and policy developments.

There are different factors at work in the formation and configuration of educational accountability in specific national contexts; to cover all of them in a substantive analysis would be beyond the scope of one single article. Therefore we will limit our primary focus to one of the main factors, culture, and try to see how global trends and forces of educational accountability have interacted with national education contexts characterized by certain cultural values.

Within national systems of education different types of accountability are generally associated with different sectors and studies focused on a single sector-for instance primary education-may miss important elements. In order to capture at least parts of this complex picture we will look at two sectors in each of the two national contexts: general school education (primary and secondary) and higher education.

After an introductory discussion of the concept of accountability and our approach we give a brief overview of education in China and Denmark as basis for our presentation and analysis on educational accountability traditions and systems in these two countries. We focus first on accountability in school education in each of the two countries and then on accountability in higher education in the two countries. On this basis we discuss the similarities and differences in systems and trends of educational accountability.

\section{Accountability, Culture, Policy}

Different types of accountability systems may be found in education. For instance Anderson (2005) distinguishes between the following three main types, namely (1) detailed institutional regulation of educational activities and compliance to this; (2) acknowledgement of professional norms and adherence to these, and; (3) specification of expected results and evaluation of performance. For all three types a range of instruments to evaluate and to improve may be used. Accountability through performance has become more widespread in many contexts during recent years, but that does not mean that institutional regulation or even professional norms have disappeared. The three types coexist in different combinations.

In a descriptive definition of accountability Wagner (1989) includes five elements:

- What level of accountability is to be provided (description, explanation, or justification)?

- Who is expected to provide the account?

- To who is the account owed?

- What is to be accounted for?

- What are the consequences of providing an account?

Using Wagner's 'for what' and 'to whom' questions we elaborate Anderson's three types of accountability mentioned above. 
Table 1

Types of Accountability

Accountability type

What is accounted for

To who

compliance with regulations

adherence to legislation and

bureaucracy and political

official orders

system

adherence to professional

professional qualifications

professional peers and

norms

and control within

professions

political system

evaluation of results

outputs (e.g. completion

bureaucracy, rates; student achievement;

employment)

political system and general

public

Professional norms specify the special qualities that members of professions, such has doctors or teachers, have to live up to. Such norms have generally been developed by the professions themselves, but in negotiation with political systems (Macdonald, 1995). We argue that what is accounted for is not the actual professional practice but rather the measures through which professional norms are upheld, like making sure that only people with the right qualifications are allowed access to work and having control mechanisms through which the profession itself corrects unsatisfactory practices. Accountability always relates to the political system, but this is combined with other collective actors in different ways. Accountability through evaluation of results addresses the most complex combination of actors because information of outputs is generally made available to the general public, partly as a deliberate effort to inform and encourage public choice.

In another dimension Dubnick (2006) has distinguished between the following four 'orders' of accountability:

- Performative accountability, which requires explicit and direct acts of account giving.

- Regulatory accountability, which does not involve direct account giving but rather following the rules and standards of the given task environment.

- Managerial accountability, which relies on demands for account giving as a means to shape the behavior of account givers

- Embedded accountability, which operates through norms and values and the account giver's internalization of a sense of moral responsibility.

The concept of embedded accountability is related to the concept of governmentality used by Foucault (2002) and developed further by others (Dean, 1999). It points to possible scenarios where authorities use accountability procedures for the purpose of installing general self-discipline in citizens and making them adhere to the given social order.

The focus of Dubnick's categories is on the character of the social relation between those demanding and those giving account. We will not try to integrate his approach with the typology above, but it is a useful supplement.

The fast growing use of the word accountability noted in the introduction clearly reflects that the issue of accountability has been taken up in education policy, not only at national but also at transnational levels. It can be argued that the modern world is increasingly characterized by a global regime of policy development, enacted partly through international organizations like the OECD but also through other types of contacts and negotiations between governments and other important 
actors (Ball, 2012; Dale \& Robertson, 2009). Diagnoses of problems, policy objectives and recipes for success are circulated, co-developed and adopted in different national contexts. With inspiration from Michel Foucault's analyses of the correlation between knowledge procedures and exercise of power (Foucault, 1980) evaluation and accreditation systems with their standardized procedures, standard set of criteria and emphasis on detailed documentation may be seen as tools for adapting higher education programs to a common set of norms for higher education, a 'standard model'.

However, accountability is not separated from other aspects of society. The type(s) of educational accountability that can arise and be institutionalized in a society depends very much on the social and political traditions of that society. Apart from the obvious difference in size and population, some important differences between China and Denmark relate to cultural values and political systems.

Some researchers have tried to develop categories suited for mapping the cultural values of different counties. A well-known example is Hofstede's theory, focusing on individualism versus collectivism, masculinity versus feminism and other dimensions (Hofstede, 2001). In the two dimensions mentioned China has a collectivistic and masculine culture, while Denmark has an individualistic and feminine culture. Another example is a multidimensional measure of cultural values developed by Schwartz (1999). He works with seven value dimensions: conservatism, hierarchy, mastery, affective autonomy, intellectual autonomy, egalitarianism and harmony. Drawing on data from a large number of countries he lays out a map where the countries are ordered into different groups, each with a distinct mix of the value dimensions. Here China belongs to a "Confucian" cultural group with a strong emphasis on hierarchy and compliance with obligations and rules while Denmark belongs to a group of European countries with emphasis on egalitarianism and intellectual autonomy.

As regards political systems the main difference is that China is a single-party state governed by the Communist Party of China. Such systems generally call for limited public competition over power and a restrained public discourse. Denmark is a state with constitutional democracy where different political parties have the opportunity to publically advocate their policies, run candidates for election and ultimately for office.

These cultural and political differences are well known, but they should not be exaggerated. Both countries are undergoing significant changes, partly spurred by the impact of globalization, and complex patterns of cultural values and political life are found. This is especially true in China, where big differences are found between traditional and modernized segments of the population.

Nevertheless some basic cultural and political differences between the two countries are still there and are relevant to the development of accountability in education.

\section{Approach}

Our approach in this article is historical and comparative. When modern governments describe their educational systems and priorities they often use the same concepts, but in fact educational systems and practices strongly depend on their history and the development of the societies in which they are embedded. To capture this we follow a historical approach in presenting first education, then educational accountability in the two national contexts. Of course the format does not allow a more detailed historical account.

Our main source of data is official policy documents and statistics, but existing research contributions, both generally and in the two national contexts, also influence the presentation of developments. We first reviewed existing discussions on the concept of accountability, based on which we developed the conceptual basis for our comparison of educational accountability in China 
and Denmark. Then we developed descriptions of the two educational systems and their accountability measures. This was the basis for comparative discussion.

We are aware that the term accountability may not have the same meaning in different national contexts and that this can complicate the interpretation of sources. However, this can be an advantage rather than a deficit for a deeper understanding of accountability. Only after the examination of its different substantiations can it be fully conceptualized and understood.

\section{Education in China and in Denmark}

\section{China}

China is one of the oldest civilizations and has a long history of state direct interference on the main aspects of social life, including education. The political system and culture has a strong emphasis on hierarchy and bureaucracy as means to unify or coordinate different local cultures in such a large country. The current politics of China take place in a framework of a socialist republic with the Communist Party of China as the country's sole political party in power.

Education in the new China (the People's Republic, founded in 1949) is mainly a state-run system of public education, which is in the charge of the Ministry of Education. Table 2 below shows an overview of the mainstream education in contemporary China (Zou, 2013, p. 23). Based on the different mechanisms of accountability it can be roughly divided into two sectors, i.e. the general school education (including both primary and secondary school education) and higher education. As described and argued below, the most notable measures of accountability are educational inspection and quality monitoring for general school sector, and undergraduate teaching evaluation, accreditation of professional programs and disciplinary ranking for higher education.

Standardized tests such as Gaokao (higher education entrance examination) could also be regarded as a form of educational accountability in China. However, the official function of Gaokao is for higher education admission and it has not been used officially as a mechanism of accountability. Still it may be used by schools to document their efforts and quality to the public, especially the parents, or even to the government.

Table 2

Mainstream Education in China

\begin{tabular}{lcccc}
\hline Education & Years & Typical Age & Students in 2010 & Institutions in 2010 \\
\hline Primary school & 6 & $6-11$ & $99,407,000$ & 257,400 \\
Junior secondary school & 3 & $12-14$ & $52,793,300$ & 54,900 \\
High school & 3 & $15-17$ & $24,273,400$ & 14,058 \\
University or college & 3 or 4 & $18-22$ & $22,317,900$ & 2,358 \\
\hline
\end{tabular}

Note: Mainstream education refers to the education that is provided by the regular schools or institutions run by the state, which does not include the adult schools or institutions, occupational high schools, special education schools, non-state or private institutions, etc. The numbers of students and institutions in 2010 are from the Ministry of Education, China (2012a). 


\section{Denmark}

Education in Denmark reflects the character of Danish society, culture and political system. Denmark is a small country without many natural resources. During the 20th century it has developed from an agricultural society to an industrial society, and then to a service and knowledge society. It has a political culture with strong emphasis on collaboration and pluralism, both in national and local matters. The historical background for this is that Denmark managed to complete the transformation from absolutism to representative democracy without major conflicts between social classes (Kaspersen, 2013).

The spectrum of political ideologies in Danish politics resembles that of other western nations, although the ideologies have adapted themselves to the historical and cultural context. The main divide in educational matters is between conservative and liberal forces on one hand, social democratic forces on the other. Danish education has developed through patterns of cooperation and conflict between these political interests. A unified public school ('folkeskole') covering the age span from 7 to 14 was introduced around year 1900, and in the 1970s mandatory schooling was extended to the age of 16 . The political parties have always tried to reach consensus in matters concerning this part of the educational system, and reforms have generally not been radical. In upper secondary education (post-16 education) Denmark has retained a system of distinct sectors, with the general and academic schools (mainly the "gymnasium") preparing students for higher education, while technical schools, commercial schools and social and health schools offer vocational education. Most students complete a secondary education degree.

Danish higher education is organized in two sectors with each their types of education programs. The university colleges run short-cycle programs as well as medium-cycle profession bachelor programs, for instance in teaching, nursing and social work. The universities run long-cycle academic programs, mainly organized according to scientific disciplines but also with elements of professional training.

Table 3

Education in Denmark.

\begin{tabular}{lcccc}
\hline Education & Years & Typical age & Students in 2010 & Institutions in 2009 \\
\hline Unified public school & 10 & $6-16$ & 716.877 & 2.642 \\
General secondary school & 3 & $17-19$ & 134.112 & 149 \\
Vocational education & $3-4$ & $17-20$ & 131.598 & 109 \\
University or college & $3-5$ & $19-24$ & 224.452 & 30 \\
\hline
\end{tabular}

Note: Based on statistics available at the Ministry of Education website and on Danish Ministry of Education (2009).

In Denmark elements of new public management, including quality control initiatives in higher education programs, were introduced between 1982 and 1993, under liberal-conservative coalition governments. The first initiative was a modernization program for the public sector in 1983, which was followed by others. Some of the keywords in this modernization were decentralization of management responsibility, abolition of detailed formal regulation, governance through a combination of objectives and allocation of resources. Public choice and the establishment of quasi-markets in public services were also emphasized. Education was one of the areas where the modernization initiatives had a strong impact. 


\section{School Education in China: Inspection and Monitoring}

\section{Educational Inspection}

Since the foundation of People's Republic of China in 1949, inspection has been used as an important mechanism of educational accountability. In 1949, the newly established Ministry of Education installed a department of inspection (National Inspectorate of Education, 2005). This department was mainly in charge of inspecting the implementation of state educational regulations and policies.

Soon after the Cultural Revolution, the recovery of the inspectorate system was put on the agenda by the government (National Inspectorate of Education, 2005). At the national conference on general education in 1983, the Ministry of Education initiated a 'Suggestions/Opinions for Establishing an Inspectorate System for General Education', which suggested to install a inspectorate into all administrative levels above county ${ }^{1}$. In 1991, the minister of education issued a 'Temporary Regulations on Educational Inspection'.

In 1993, the state council released an 'Outline of Educational Reform and Development in China', which stipulated the construction of quality criteria and indicators for all kinds of education as well as regular inspection of the educational quality of schools. In the same year, an 'Educational Inspection Office' was established under the National Committee of Education ${ }^{2}$. In 2000, this ministerial office of educational inspection was renamed as National Inspectorate of Education. And a national system of educational inspection has gradually taken shape with corresponding regulations and working procedures in both local and central administrations. This is a four-level system of educational inspection, that of the central government, the province, the prefecture (or city), and the county (National Inspectorate of Education, 2005).

According to the new National Regulations on Educational Inspection issued 2012 by the Chinese state council, educational inspection covers two elements (State Council, China, 2012):

- Higher level government's inspection on lower level government's implementation in educational law, regulations and policies;

- Government's inspection on schools in their educational activities.

And the inspection is about direct check and evaluation of school activities by specialized experts. The aspects to be inspected include (Ministry of Education, 2012b):

- Comprehensiveness of internal documents such as regulations, planning, employment of modern management mechanisms, etc.

- Efficiency in resource utility such as financial audit, use of infrastructure and facilities, staff development, etc.

- Enhancement of teaching quality such as sticking to national curriculum plan and disciplinary criteria, teaching innovation, etc.

- The development of the students such as moral traits, scientific traits, physical and psychological health, interest in study, aesthetic appreciation, practical skills, innovativeness, etc.

\footnotetext{
${ }_{1}^{1}$ The main government levels/divisions are the central government, the province, prefecture (or city), county, township, and village. There are also four cities (Beijing, Shanghai, Tianjin and Chongqing) which are under the direct jurisdiction of the central government and thus province equivalent.

${ }^{2}$ Ministry of Education in China was changed to National Committee of Education in 1985, and then was changed back as Ministry of Education in 1998.
} 
It should be noted that although 'scientific traits' is mentioned, the guidelines do not seem to give special emphasis to academic learning and achievement compared to others. However, since the academic traits are more easily measured they may in practice become more visible.

According to the inspection regulation (State Council, China, 2012), the inspection reports should be made public and serve as a basis of award and punishment of the inspected school and school leader. The inspected are also required to make improvement according to the inspection conclusions.

\section{Quality Monitoring}

The result-based accountability in China, in the form of performance evaluation or quality monitoring, is rather new compared to educational inspection. It was launched with the establishment of a national center in 2007, i.e. the National Assessment of Education Quality as appears at its official website; but if literally translated from Chinese it is Ministerial Center for Quality Monitoring in Primary and Secondary Education. And gradually there are also quality monitoring centers established at the provincial level. This initiative is regarded as a response to the widespread use of the entrance examination result as the main criterion for educational quality $(\mathrm{Li}$, 2010). Government feared that the exaggerated focus on the promotion rate (the ratio of students who pass the entrance examination and gain access to the next stage of education) would lead to 'education for examination' and tried to counter this by introducing quality monitoring.

Thus this newly established quality monitoring and assessment is supposed to offer a more comprehensive and effective way of educational evaluation and accountability. Quality monitoring is about constantly watching and measuring the educational outcomes, which include (National Assessment of Educational Quality, n.d.):

- The students' moral traits and citizenship;

- The students' physical and psychological health;

- The students' academic achievement and learning ability;

- The students' artistic traits;

- The students' practical skills and innovativeness;

- Educational and social environments that influence students' development.

The aim of this quality monitoring is to learn about or diagnose the educational status (of a school or region) and the influencing factors, and to form the information basis for educational decisionmaking. The assessment and monitoring results are to be reported to the central, provincial and county governments. This monitoring is targeted at the overall status, not individual student or school. And there is no ranking, no grading, no released score (National Assessment of Educational Quality, 2008). This signals that the system is not intended to produce information for educational markets.

Quality monitoring has now become an issue on the agenda of the National Inspectorate of Education, according to its released agenda in 2013. And we can say that it is, at least partly, incorporated into the inspectorate system.

\section{Combined Elements of Accountability}

Accountability in school education in China first took the form of inspection, with compliance to state regulations as its main concern. Then the result-based quality monitoring has been developed (partly to balance the widespread focus on the entrance examinations) in parallel with inspection, and is now getting more and more public attention.

This development of school education accountability has showed that in China there is a combination of elements of all the three types of accountability we outlined earlier. The inspection 
and quality monitoring activities are initiated and organized by the government. However, the central involvement of experts in those activities reflects the respect to professional norms. The introduction of regulations on teacher's certificate, stipulating that all those who would like to be teachers should first get proper qualifications in terms of level of education, subject knowledge and pedagogical training, is also an aspect of respect to professional norms.

\section{School Education in Denmark: The Growth of Assessment Systems}

Responsibility for the unified public school is located at two levels; the municipalities build, finance and staff schools, while the state decides the structure, the overall curriculum, the content of school-leaving examinations and also the qualifications needed for teachers.

\section{Detailed Regulation and Local Participation}

Traditionally accountability has been a question of detailed regulation from the Ministry of Education, covering both the curriculum and the activities in schools. Fifty years ago handbooks for teachers consisted of several volumes of ministerial orders on all aspects of life in schools. This detailed regulation was given up in the 1980s as part of the modernization of the public sector and many aspects of daily life in schools is now regulated more locally. However, there has often been a trend to reintroduce central regulation because of public and political awareness of the school from parents, media and other stakeholders. Problems in this field are often raised in public debate, and political actors compete to remedy them through new rules and initiatives.

A particular aspect of accountability in general school education is accountability towards parents. This has mainly consisted in parent involvement in local school decision-making. In the years after the Second World War democratization was an important agenda in many parts of society. In the 'folkeskole' the possibility of establishing formal teacher-parent committees was introduced, and in 1970 such committees were made mandatory for all schools (Ravn, 2011). In the 1980s school boards supplanted this with more real influence on school management and with a formalized election procedure for the appointment of parent representatives (Sørensen, 1998). School boards signal a degree of local accountability towards parents, but not towards other local stakeholders (for instance the secondary schools); and their role in school decision-making remains limited.

\section{Accountability Through Assessment}

Detailed regulation of general school education has in fact been reduced and more outcomes-oriented measures have been introduced. A major event was the 2006 school reform, which followed a period of intense public debate on the quality of schooling and teaching, sparked especially by disappointing Danish scores in the PISA surveys. The debate resulted in calls from many quarters for more evaluation and assessment, and this was incorporated in the school reform (Ministry of Education, Denmark, 2008; Shewbridge, Jang, Matthews, \& Santiago, 2011). The role of exams in schooling was strengthened, with exams in more school subjects and starting at an earlier age. A system of national tests was introduced. The main function of these was to allow the state to monitor the national levels of achievement, but they could, to some extent, also be used by teachers to give feedback to students and parents. A specialized unit for school assessment and evaluation was established in the Ministry of Education. Associated with the unit was a national council of important actors from the school system. The tasks of the unit and the committee were to produce regular reports on the quality of schooling and student achievement. At the municipal level an annual school quality report was introduced. The quality report should describe the municipality's 
school system, the levels of achievement and steps taken by the municipality to uphold and improve quality. A new school reform introduced in 2014 has continued these accountability measures.

\section{Teachers and Transparency}

A further dimension of school accountability is the provision of open and transparent information on educational institutions. This is regulated by a public order introduced in 2005, obliging all educational institutions to publish on their websites relevant information about their activities, such as curricula, mission statements, completion rates and results from evaluations of teaching. This is a type of accountability aimed directly at the general population. It is often supplemented by quality surveys conducted by the municipalities (Rasmussen, 2012).

Teacher education also contributes to accountability. In Denmark teachers for primary and lower secondary schooling are educated in specialized programs at university colleges. Reform of teacher education is often seen by governments as a way to assure the quality of teaching in schools (Carlgren \& Klette, 2008). The most recent reform of teacher education has a focus on improving teacher professionalism in a combination of subject knowledge, pedagogical knowledge and practical training.

Like in China, the school education accountability in Denmark includes all the three types of accountability we outlined earlier. A special feature of Danish accountability has been the emphasis on accountability towards parents through involving them in school governance. In recent years the emphasis has been more on providing information on different aspects of school quality as a basis for parent and student choice.

\section{Higher Education in China: Evaluation, Accreditation, Ranking}

\section{Undergraduate Teaching Evaluation on Higher Education Institutions}

Institutional evaluation as an accountability mechanism in Chinese higher education started soon after the Cultural Revolution. It was tried out in 1985 and in 1990 a specialized regulation on evaluation, 'Regulations on Evaluation of Regular Higher Education Institutions', was released by the government. However, the concern with quality assurance and accountability systems in Chinese higher education has been relatively limited until the 'big expansion' that began in 1999. In 2002 China started to develop a nation-wide formal evaluation system. A 'Plan for Undergraduate Teaching Evaluation in Regular Higher Education Institutions' was formulated by the Ministry of Education in the same year. The revision of this plan in 2004 served as the government's primary guidelines in the first round of undergraduate teaching evaluations (Ministry of Education, 2004a). Based on the 'Action Plan of Education Innovation 2003-2007', all higher education institutions were required to undergo a quality evaluation every five years (Ministry of Education, 2004b). And a Higher Education Evaluation Center (HEEC) was established in 2004 to serve as the national coordinating body for the evaluation. Since then, the formal higher education evaluation system gradually took its shape.

The evaluation starts with institutional self-evaluation where a self-evaluation report is produced and submitted to the ministry. Then a group of academic peers conduct a site visit and review the institutional activities, at least partly on the basis of the self-evaluation report. After the peer review, the feedback will be given to the institution and the evaluation results in the form of a grade of Excellent, Good, Acceptable, or Not Acceptable, will be released publicly on the website of the Higher Education Evaluation Center. And finally the institutions will produce an action plan for improvement. The primary indicators of the evaluation are (Ministry of Education, China, 2004a):

- Guiding ideas for running the university 
- Teaching staff

- Teaching facilities and its usage

- Program construction and teaching innovation

- Teaching management

- Learning atmosphere

- Teaching outcome

- Special characteristics (of the institution in question)

\section{Disciplinary Ranking in Higher Education}

While the focus of undergraduate teaching evaluation is the whole institution, the focus of disciplinary ranking is certain disciplines in the institution in question. In Europe this approach has especially been used in the 'Research Assessment Exercise' system used in England. Disciplinary ranking has been conducted by Ministerial Center for Academic Degrees and Graduate Education Development since 2002. There have been 3 rounds of ranking until now. The primary focus is the quality of specific disciplines or programs, which resulted in league tables of institutions for each discipline. The participation is voluntary for the institutions - any institution that is eligible to confer a postgraduate degree in certain discipline can choose to participate (or not to participate) in the ranking in that discipline. Except two '211 institutions', all the key universities (the 211 and 985 institutions ${ }^{3}$ ) participated in the 2012 ranking (Chai, 2013). The primary indicators are the following aspects of certain discipline (China Academic Degrees and Graduate Education Information, 2012):

- Faculty and resource

- Research level

- Student quality

- Disciplinary reputation.

The raking result is publicly available (officially on the website of China Academic Degrees and Graduate Education Information run by the Center, and it also reproduced by other major Chinese websites such as China Education Online, Sina and qq.com).

\section{Program Accreditation in Engineering and Medicine}

Recent development in accountability in Chinese higher education also includes the adoption of an accreditation system in professional fields such as engineering (since 2006) and medicine (since 2008). Since the accreditation procedures in these two fields are similar to each other, the following discussion will mainly take the first started engineering education accreditation as an example.

The Ministry of Education established an expert committee to take charge of the accreditation of engineering education in 2006. Based on the experience of trial accreditation, the 'National Trial Measures for Engineering Education Accreditation' was released by the Ministry in 2007, stipulating how the accreditation should be implemented. The accreditation covers six stages (Ministry of Education, China, 2007):

- Application (accreditation is voluntary to institutions and they should first apply for accreditation);

- Self-evaluation and submission of self-evaluation report to the committee;

- Check and approval of the self-evaluation report by the committee according to the 'Standard for Accreditation of Engineering Programs';

\footnotetext{
${ }^{3}$ Project 211 and Project 985 are two key university projects initiated by the Chinese government. Institutions admitted in these two projects are mostly well-reputed and are prioritized in financial and other resource support by the government.
} 
- Site visit by expert group delegated by the committee;

- Discussion and accreditation conclusion made by the committee;

- Maintenance of the accreditation status (the accredited institution should report to the committee every year or every two years).

The 2011 version of the 'Standard for Accreditation of Engineering Programs' includes both general and program-specific criteria (see Table 4).

Table 4

Standard for Accreditation of Engineering Programs in China

\begin{tabular}{|c|c|c|}
\hline Type & Criteria & Specification \\
\hline \multirow[t]{7}{*}{ General criteria } & Program goal & $\begin{array}{l}\text { Program setting } \\
\text { Graduate competences }\end{array}$ \\
\hline & Curriculum system & $\begin{array}{l}\text { Curriculum plan } \\
\text { Practical training } \\
\text { Thesis (design) for graduation }\end{array}$ \\
\hline & Faculty & $\begin{array}{l}\text { Faculty structure } \\
\text { Faculty development }\end{array}$ \\
\hline & Facilitating conditions & $\begin{array}{l}\text { Teaching finance } \\
\text { Teaching facilities } \\
\text { Information resource } \\
\text { Industrial collaboration }\end{array}$ \\
\hline & Student & $\begin{array}{l}\text { Student source } \\
\text { Employment } \\
\text { Student supervision }\end{array}$ \\
\hline & Management & $\begin{array}{l}\text { Teaching policy and regulation } \\
\text { Process control and feedback }\end{array}$ \\
\hline & Quality evaluation & $\begin{array}{l}\text { Internal evaluation } \\
\text { Social/external evaluation } \\
\text { Continuing improvement }\end{array}$ \\
\hline Program-specific criteria & \multicolumn{2}{|c|}{ According to specific programs } \\
\hline
\end{tabular}

The issue of student employment is included in the framework, but does not seem to have special importance, at least not formally. The conclusion of this engineering education accreditation could be 'pass, valid for six years', 'pass, valid for 3 years' or 'non-pass'. And this result will be released by Ministry of Education on its website.

For medical education, there is the 'Standard for Undergraduate Medical Education' on which the accreditation is based. And the accreditation result is 'accredited', 'conditional accredited' or 'not accredited'. 


\section{A Complex System of Accountability}

The accountability system in the higher education sector of China is a complex one in the sense that it has a representative of all the three types of accountability outlined at the first section of this paper-teaching evaluation is a representative of compliance-with-regulations type of accountability, disciplinary ranking a representative of evaluation-of-results, and accreditation a representative of adherence-to-professional-norms.

The development of this accountability system has shown a change from the traditional government hegemony on higher education to more involvement of other stakeholders in the issues of higher education. Although the government still mainly organizes the accountability activities, it does not have the monopoly any more. This must be seen on the background of the expansion and diversification of Chinese higher education, where it needs to raise resources from alternative sources and cover interests of different groups. Since 1999 there has been a rapid increase of students enrolled in Chinese higher education, more institutions have been established, and a diversity of new programs have emerged. This change involves many more people in higher education and raises public concern over the quality issue in higher education. For example, is the higher education system capable of including so many students? Can academic standards be properly kept with the newly established institutions and programs? This has created a demand for more public accountability in higher education.

\section{Higher Education in Denmark: From Evaluation to Accreditation}

Accountability in Danish higher education has traditionally consisted of some political regulation combined with a strong element of collegiate governance and peer assessment. Government allotted funds and decided on a system of disciplines and degrees. Quality teaching was assumed to be assured by the excellent knowledge of university professors, and decisions on the practical arrangement of educational programs and teaching was left to the academics in the different disciplines. In the 1970s legislation introduced a strong element of participatory democracy in Danish universities (Kreisler, 2006); this meant increased accountability towards students, but not towards other stakeholders.

\section{Evaluation Center for Higher Education}

This situation was gradually changed through a move towards modernization of the public sector. In 1992, after years of debate, the Ministry of Education established the Evaluation Centre for Higher Education. Its task was to evaluate all Danish higher education programs. The Evaluation Centre was an independent institution affiliated with the Ministry of Education. The institutions of higher education were obliged to cooperate on evaluating their education programs, but the center did not have authority to initiate evaluations on its own. This authority was placed in the Ministry of Education, and the policy was to evaluate all higher education programs at least every five years; usually not entire institutions, but rather programs within a certain discipline and at all institutions that offered the relevant programs (Thune, 1997). For instance one of the first programs evaluated was history, which existed in five institutions. The evaluations strongly resembled comparisons of practice at the different universities (Rasmussen, 1997).

Evaluations usually comprised three elements; (1) a self-evaluation by each education program; (2) user surveys of students, graduates and employers; (3) visits to the educational institutions usually conducted by the evaluation steering group. It was initially unclear how the

results of the evaluation center's investigation would be used. Could they lead to closings of programs and if so what would the decision making process look like? The Ministry of Education 
gradually introduced standard procedures that committed the educational institutions to follow up on the evaluations and report to the ministry.

In 1999, when the Evaluation Centre was completing the first round of recurrent evaluations, it was renamed the Danish Evaluation Institute (EVA) and its new task was to conduct equality assessment and quality improvement in the entire Danish educational system. The main methods from the evaluation center model continued to be used, but recurrent evaluations were replaced by a spot check principle.

\section{Introduction of Accreditation}

More than a decade later a new system of accountability was introduced: accreditation. In the United States accreditation procedures have played a large role in higher education for a long time, because many higher education institutions have depended on private funding from different stakeholders, who have demanded benchmarking of quality. In Europe, where higher education institutions have mainly been funded and run by the state, the interest was limited until the 1990s when a number of European countries started introducing systems for accreditation of higher education programs. The pioneers were Central and Eastern European countries, and Hungary introduced the first system in 1993 (Teichler, 2007). One reason for this may have been that after the collapse of the old regimes many universities hoped to ensure their autonomy via independent evaluation and recognition of study programs.

In Denmark accreditation was introduced in connection with new legislation on universities and other higher education. In the university act of 2004 and in the equivalent legislation for other higher education one objective was to strengthen the educational institutions' administrative and economic autonomy. The establishment of new education programs was one of the problematic issues in this context. Denmark has a long tradition for central control of this area, and decisions to create and cancel education programs have rested mainly with the civil servants in the relevant ministry. The introduction of an accreditation system for higher education can be seen as a strategy to move these conflict-prone decisions out of the ministerial bureaucracy without giving up the centralized decision making competence (Rasmussen, 2011).

The Danish act on accreditation of institutions for higher education was passed in 2007. The act required that all higher education programs in Denmark had to be accredited. New education programs should be accredited before they are launched, and accreditation should be separate for all institutional localities before a program was offered. Existing programs should be accredited regularly.

The act established an accreditation council consisting of a limited number of ministryappointed experts. The analytical and administrative procedures in connection with accreditation of vocational higher education programs were placed with EVA (the Danish Evaluation Institute). For the research-based university programs a new unit called ACE Denmark was established.

The procedures of accreditation in many ways follow the model developed by the evaluation center in the 1990s. For each accreditation an expert panel follows the work, participates in visits to institutions and is responsible for the conclusions of the accreditation report. The staff at ACE Denmark and EVA conducts the practical work. The institutions whose study programs are up for accreditation prepare detailed applications after standard templates based on the accreditation criteria. The applications are assessed by the evaluation staff and by the steering group. Based on this and the results from the site visit a report is prepared and the conclusion is a recommendation for accreditation or non-accreditation. The report is the basis for the accreditation council's decision (ACE Denmark, 2012). 
In 2013 the system was reformed, accreditation of existing higher education programs being replaced by accreditation of whole institutions. This was partly a result of an evaluation of the 2004 university act where the international panel commented that the Danish accreditation system reflected too little confidence in universities' ability to maintain educational quality (Ministry of Science and Innovation, Denmark, 2009). In the reformed system ACE Denmark and the accreditation council evaluate each university's procedures for assuring the quality of their education programs, and if the results are satisfactory the university is accredited. However, all new education programs must be pre-accredited by the Ministry of Higher Education before they can be offered to students.

One of the criteria for accreditation is that institutions undertake regular evaluation of their teaching. This almost always takes the form of questionnaires filled by students and summarized by evaluation units in the institutions. The use of such evaluations had grown during the 1990s, and in 2005 their role was strengthened by the public order on open and transparent information mentioned earlier. According to this order, results from teaching evaluations were part of the information that educational institutions should publish on their websites.

All in all, accountability in Danish higher education is at present dominated by the accreditation model, which can be characterized as quality assurance according to standard procedures; mainly external, with limited internal elements; mainly summative and with application of multiple approaches, including the academic, the administrative and the user-oriented.

\section{Discussion and Comparison}

For much of the post-war period educational accountability in both China and Denmark mainly consisted in detailed regulation of institutions and practices. An element of professional accountability was also present, especially in higher education and perhaps somewhat more in Denmark than in China. During the last two decades accountability through evaluation of results has been taken up and has gradually become dominant. Detailed regulation and professional norms have not disappeared, but they are used more selectively and redefined as means to secure output.

In general school education in China seems to have had a stronger tradition of inspection procedures than Denmark. This may be a legacy of a "Confucian" tradition with a strong emphasis on hierarchy and compliance with obligations and rules. In Denmark there have been stronger elements of accountability towards parents, reflecting the more pluralist and egalitarian culture of Danish society. However, this has increasingly been supplemented by measures to measure the activities and performance of schools, and to make this information available to the public. 'Horizontal' accountability increasingly takes the form of market information.

The fact that Denmark started to introduce results-based accountability in school education earlier than China probably reflects the stronger presence of market-based regulation in Western Europe, as evidenced especially through the importance given to the transnational PISA surveys.

Another element that corresponds to the difference between Confucian and liberal traditions is that school evaluation in China includes the development of students in many dimensions, including moral traits, scientific traits, physical and psychological health. In Denmark schools are also expected to foster personal and social skills, but it would not be perceived as legitimate for the state to control these, so performance accountability focuses almost exclusively on skills and knowledge in school subjects.

However, the reforms implemented in both countries during the last 10-15 years are not so different from each other. Both involve documentation of activities and achievements at local and central levels. And in both countries there is a trend towards accountability through evaluation of 
outputs, but it is combined with both regulations and professionalism. An interesting aspect will be to see how the role of professional accountability in general school education develops in the two countries.

The role of accountability has always been stronger in general school education than in higher education, historically because schooling was one of the ways states shaped and controlled their citizens, politically because citizens are also parents who concern themselves with the opportunities of their children. However, in recent decades the demand for accountability in higher education has increased dramatically in much of the world. This must be seen on the background of the massive growth of enrolments which has transformed higher education from an elite to a mass system (Trow, 2007), and which in turn has led governments to be much more concerned with the allocation of resources and the cost-effectiveness of higher education institutions.

The change is also evidenced in Denmark and China, where several accountability systems have been devised and implemented. But there are differences in the types of accountability pursued in the two countries. Denmark introduced a systematic model of evaluation in the 1990s, a model that subjected all higher education programs to comprehensive inspection at regular intervals. After some years the model was given up, but when accreditation was introduced a decade later many of the same evaluation procedures were used. In accordance with the principles of new public management accreditation presupposes that higher education institutions are independent actors who apply for recognition of 'their' study programs. In China models of quality assurance in higher education were developed some years later than in Denmark, but have been implemented quickly in the new millennium. Undergraduate teaching evaluation was the first model implemented and it has recently been supplemented with accreditation of study programs in selected fields. The main difference between the two countries is that China also operates a system of disciplinary rankings, where institutions are ranked in the main disciplines according to research output, student quality, reputation and other features. Compared to evaluation of higher education institutions, accreditation and disciplinary ranking is more result-oriented than direct regulation. That such a system has not yet been introduced in Denmark (although it has been discussed) can be seen as result of the strong element of egalitarianism in Danish culture.

Especially in higher education China has a more complex system of accountability with different elements running in parallel (detailed regulation, result driven, professional norms). There may be several reasons for this. The massive growth in higher education enrolments started later in China, so Chinese authorities are still experimenting with different systems. And Chinese higher education is embedded in a large and complex society that is undergoing dynamic social change. In comparison Denmark evolves fairly steadily along a path based on the Nordic welfare state model and influenced by common European Union priorities.

Denmark and China both move towards output-based types of quality assurance and implement models (like teaching evaluation and accreditation in higher education) that strongly resemble each other. This can be seen as result of the global education policy regime that we noted earlier in the paper. International organizations and many other types of inter-government contacts provide common concepts and tools for identifying problems in education and devising policy responses to them. This does not make accountability policies identical across the world, but it does establish degrees of similarity, especially in the rhetoric and the formal description of systems.

An example from the Danish case is the qualification framework for higher education, based on common EU policy, which is to be incorporated in study programs for all higher education. The use of the qualification framework has been decided politically; but its principles and concepts are fairly open and not without contradiction. In principle, it is up to the institutions of higher education to implement the qualification framework; but in reality this is governed by the accreditation system. 
The ways the accreditation officials interpret the qualification framework is forced on the institutions through the application and assessment procedure. In the terms of Dubnick (2006) the accountability of the qualification framework gradually becomes embedded.

In both countries the international policy regime has had a much stronger impact on accountability in higher education than in school education. This is because higher education is less embedded in the basic cultural values of the two societies. The historical development of modern higher education has involved much interaction between educators, researchers and administrators in different countries, and international flows of students and researchers means continuous informal education. This contributes to the infrastructure of international education policy regimes.

\section{Conclusion}

Although China and Denmark are very different in terms of size, history and culture, educational policy in both countries is marked by an increasing concern with accountability, and there are considerable similarities in the types of accountability pursued. In both countries, and in general school education as well as higher education, the current accountability mechanism is a combination of regulative, professional and result-based accountability. Context-specific variations in procedures exist and the impact on institutional cultures and educational practices is influenced by the cultural and political traditions of the two countries. China and Denmark can be said to be moving through different trajectories towards a similar trend.

Recent years have been marked by a general move towards adopting result-based forms of accountability and integrating them with earlier regulative forms. This is seen most clearly in higher education, where many institutions and actors are linked to global networks. There is also increasing awareness of accountability based on professionalism, although there are tensions between this and both result-based and bureaucratic forms of accountability. But the dominant trend is result-based accountability, rooted in the logic of New Public Management (Tolofari, 2005). The idea of this is that through the 'invisible hand' of markets and quasi-markets for public services, citizens can choose services according to their own preferences and regulation by bureaucratic and political institutions. However, as Foucault (2002) emphasized in his analysis of liberalism, market logic is intimately connected with a political logic co-constructing the environments and the implications of market decisions. So instead of creating the basis for informed rational decisions, result-based forms of accountability, the 'rule by nobody' (Arendt, 1998, pp. 40-45) may serve to divert attention from the unequal access to economic, cultural and political resources among those being educated and accounted for. This undermines the potential for spontaneous or autonomous actions as discretion gradually slip out of educational actors' hands.

\section{References}

ACE Denmark. (2012). Accreditation - Why and how. Copenhagen: ACE Denmark.

Anderson, J. A. (2005). Accountability in education. Paris: The International Academy of Education and Brussels: The International Institute for Educational Planning.

Arendt, H. (1998). The human condition. Chicago: The University of Chicago Press. http://dx.doi.org/10.7208/chicago/9780226924571.001.0001

Ball, S. J. (2012). Global education Inc: New policy networks and the neo-liberal imaginary. London and New York: Routledge. 
Carlgren, I., \& Klette, K. (2008) Reconstructions of Nordic teachers: Reform policies and teachers' work during the 1990s. Scandinavian Journal of Educational Research, 52(2), 117133. http://dx.doi.org/10.1080/00313830801915754

China Academic Degrees and Graduate Education Information. (2012). Introduction to disciplinary ranking (in Chinese xueke pinggu jianjie). Retrieved May 31, 2013 from the website of China Academic Degrees and Graduate Education Information at http://www.chinadegrees.cn/xwyyjsjyxx/xxsbdxz/276985.shtml

Dale, R., \& Robertson, S., (Eds.). (2009). Globalisation and Europeanisation in education. Oxford: Symposium Books.

Dean, M. (1999). Governmentality: Power and rule in modern society. London and New York: Sage.

Dubnick, M. (2006). Orders of accountability. Paper prepared for World Ethics Forum, University of Oxford, UK.

Dubnick, M. (2012). Accountability as cultural keyword. Prepared for a presentation at a seminar of the Research Colloquium on Good Governance, Netherlands Institute of Government, 9- May 2012, VU University, Amsterdam NL.

Foucault, M. (1980). Power/Knowledge. C. Gordon (Ed.). Brighton: Harvester Press.

Foucault, M. (2002) Governmentality. In J. D. Faubion, (Ed.), Power: Essential works of Foucault 1954-1984, vol. 3. (pp. 201-222). London: Penguin Books.

Hofstede, G. H. (2001). Culture's consequences: Comparing values, behaviors, institutions and organizations across nations. London and New York: Sage.

Kaspersen, L. B. (2013). Denmark in the world. Copenhagen: Hans Reitzel.

Kreisler, J. (2006). Discursive battles about the meaning of university: The case of Danish university reform and its academics. European Educational Research Journal, 5(3-4), 210-220. http://dx.doi.org/10.2304/eerj.2006.5.3.210

$\mathrm{Li}, \mathrm{J}$. (2010). China enhances the quality monitoring of basic education (news from Xinhua News Agency, in Chinese woguo jiaqiang jichu jiaoyu zhiliangjiance, jiance xuesheng quanmian suzhi). Retrieved May 31, 2013 from the Chinese central government website at http://www.gov.cn/jrzg/2010-11/29/content_1755670.htm

Macdonald, K. M. (1995). The sociology of the professions. London: Sage.

Ministry of Education, China. (2004a). Plan for undergraduate teaching evaluation in regular higher education institutions [in Chinese putong gaodeng xuexiao benke jiaoxue gongzuo shuiping pinggu fang'an]. Beijing: Ministry of Education, China.

Ministry of Education, China (2004b). Action plan of education innovation 2003-2007 [in Chinese 2003-2007 jiaoyu zhenxing xingdong jihua]. Beijing: Ministry of Education, China.

Ministry of Education, China. (2007). National trial measures for engineering education accreditation (in Chinese quanguo gongcheng jiaoyu zhuanye renzheng shidian banfa). Retrieved May 31, 2013 from Ministry of Education website at http://www.moe.gov.cn/publicfiles/business/htmlfiles/moe/cmsmedia/image//UserFi les/File/2008/05/08/2008050819/2008050819_114569.doc

Ministry of Education, China. (2011). Standard for accreditation of engineering programs (in Chinese gongcheng jiaoyu zhuanye renzheng biaozhun (shixing)). Retrieved May 31, 2013 from Ministry of Education website at http://www.moe.gov.cn/ewebeditor/uploadfile/2011/10/08/20111008173038841.doc

Ministry of Education, China. (2012a). Statistical newsletter of educational development in 2010 [in Chinese 2010 nian quanguo jiaoyu shiye fazhan tongji gongbao]. Retrieved April 11, 2012 from website of Ministry of Education at 
http://www.moe.gov.cn/publicfiles/business/htmlfiles/moe/moe_633/201203/132634 .html.

Ministry of Education, China. (2012b). Press release on 'Ministerial Opinions on Further Enhancing the Inspection of Primary and Secondary Schools' by officer of the inspection office, Ministry of Education [in Chinese jiaoyubu dudaoban fuzeren jiu <jiaoyubu guanyu jinyibu jiaqiang zhongxiaoxue dudao pinggu gongzuo de yijian>da jizhe wen]. Retrieved May 31, 2013 from website of Ministry of Education at http://www.moe.edu.cn/publicfiles/business/htmlfiles/moe/s271/201209/142328.htm

Ministry of Education, Denmark. (2008). The Folkeskole. Factsheet. Copenhagen: Ministry of Education.

Ministry of Education, Denmark. (2009). Fact and Figures 2009. Copenhagen: Ministry of Education.

Ministry of Science and Innovation, Denmark. (2009). Universitetsevalueringen 2009. Evalueringsrapport. Copenhagen: Ministry of Science and Innovation.

National Assessment of Educational Quality, China. (2008). What are the characteristics and differences of quality monitoring from the usual examinations? (in Chinese jichu jiaoyu zhiliang jiance yu yiban de kaoshi you shenme qubie he tedian?) Retrieved May 31, 2013 from its official website at http://www.eachina.org.cn/viewthread.shtml?tid $=53$

National Assessment of Educational Quality. (n.d.). Introduction to National Assessment of Education Quality (in Chinese jiaoyubu jichu jiaoyu zhiliang jiance zhongxin jianjie). Retrieved May 31, 2013 from its official website at http://www.eachina.org.cn/introduce.php

National Inspectorate of Education. (2005). Introduction to National Inspectorate (in Chinese guojia jiaoyu dudao zhidu jianjie). Retrieved May 31, 2013 from website of Ministry of Education at http://www.moe.gov.cn/publicfiles/business/htmlfiles/moe/moe_901/index.html

Neave, G. (1988). On the cultivation of quality, efficiency and enterprise: An overview of recent trends in higher education in Western Europe, 1986-88. European Journal of Education, 23(1-2), 7-23. http://dx.doi.org/10.2307/1502961

Rasmussen, P. (1997). A Danish approach to quality in higher education: The case of Aalborg University, in J. Brennan, P. de Vries, \& R. Williams (Eds.), Standards and quality in higher education (pp. 245-275). London: Jessica Kingsley Publishers.

Rasmussen, P. (2011). Evaluering og akkreditering af videregående uddannelser. In K. Andreasen, N. Friche, \& A. Rasmussen (Eds.) Målt \&vV Vjet: Uddannelsesforskning om evaluering (pp. 61-81). Aalborg: Aalborg University Press 2011.

Rasmussen, P. (2012). The politics of user satisfaction surveys in school policy. In J. Kivirauma et al. (Eds.), Social perspectives on education (pp. 105-120). Jyväskylä: FERA 2012.

Ravn, B. (2011). Skole-hjem samarbejdets historie. Dansk Pædagogisk Tidsskrift 2011(1), 27-36.

Schwartz, S. H. (1999). A theory of cultural values and some implications for work. Applied Psychology: An International Review, 48(1), 23-47. http://dx.doi.org/10.1111/j.14640597.1999.tb00047.x

Shewbridge, C., Jang, E., Matthews, P., \& Santiago, P. (2011). OECD reviews of evaluation and assessment in education: Denmark. Paris: OECD.

State Council, China. (2012). Regulations on educational inspection. Retrieved May 31, 2013 from the Chinese central government website at http://www.gov.cn/zwgk/201209/17/content_2226290.htm

Sørensen, E. (1998). New forms of democratic empowerment: Introducing user influence in the primary school system in Denmark. Statsvetenskaplig Tidskrift, 101(2), 129-143. 
Teichler, U. (2007). 'Accreditation: The role of a new assessment approach in Europe and the overall map of evaluation in European higher education', in S. Schwarz \& D. F. Westerheijden (Eds.), Evaluation and accreditation in the European higher education area (pp. 5564). Dordrecht: Kluwer Academic Publishers.

Trow, M. (2007). Reflections on the transition from elite to mass to universal access in modern societies since WWII. In P. Altbach (Ed.), International handbook of higher education. Volume 18 (pp. 243-280). Dordrecht: Kluwer. http://dx.doi.org/10.1007/978-1-4020-4012-2_13

Thune, C. (1997). The balance between accountability and improvement: The Danish experience. In J. Brennan, P. de Vries, \& R. Williams (Eds.), Standards and quality in higher education (pp. 87-103). London: Jessica Kingsley Publishers.

Tolofari, S. (2005). New public management and education. Policy Futures in Education, 3(1), $75-$ 89. http://dx.doi.org/10.2304/pfie.2005.3.1.11

Wagner, R. B. (1989). Accountability in education: A philosophical inquiry. New York: Routledge.

Zou, Y. (2013). Quality of higher education: Organizational and educational perspectives - A study in the Chinese context. Aalborg: River Publishers. 


\section{About the Authors}

Palle Rasmussen

Aalborg University

palleras@learning.aau.dk

Palle Rasmussen is professor of education in the Department of Learning and Philosophy, Aalborg University, Denmark. His research interests include educational policy, sociological theories of education and learning; educational evaluation; professional education and lifelong learning in education and work contexts. He is a member of the Danish national research council for Culture and Communication.

Yihuan Zou

Central China Normal University

yihuan@mail.ccnu.edu.cn

Yihuan Zou is an assistant professor at School of Education, Central China Normal University. His main research interests cover the sociology of education, educational policy, higher education, and learning theories.

\section{About the Guest Co-Editors}

Sherman Dorn

Arizona State University

sherman.dorn@asu.edu

Sherman Dorn is the author of Accountability Frankenstein (2007) as well as a number of articles on the history of accountability and related policies in the United States. He is currently a professor of education and director of the Division of Educational Leadership and Innovation at Arizona State University's Mary Lou Fulton Teachers College.

Christian Ydesen

Aalborg University cy@learning.aau.dk

Christian Ydesen is the author of The Rise of High-Stakes Testing in Denmark, 1920-1970 (2011) as well as a number of articles on the history of educational testing and accountability in Denmark and wider Scandinavia. He is currently an assistant professor of evaluation and testing at the Department of Learning and Philosophy at Aalborg University, Denmark. 


\section{education policy analysis archives}
Volume 22 Number 121
December $8^{\text {th }}, 2014$
ISSN 1068-2341

(c)

SOMREFIGHISRESERNED Readers are free to copy, display, and distribute this article, as long as the work is attributed to the author(s) and Education Policy Analysis Archives, it is distributed for noncommercial purposes only, and no alteration or transformation is made in the work. More details of this Creative Commons license are available at http://creativecommons.org/licenses/by-nc-sa/3.0/. All other uses must be approved by the author(s) or EPAA. EPAA is published by the Mary Lou Fulton Institute and Graduate School of Education at Arizona State University Articles are indexed in CIRC (Clasificación Integrada de Revistas Científicas, Spain), DIALNET (Spain), Directory of Open Access Journals, EBSCO Education Research Complete, ERIC, Education Full Text (H.W. Wilson), QUALIS A2 (Brazil), SCImago Journal Rank; SCOPUS, SOCOLAR (China).

Please contribute commentaries at http://epaa.info/wordpress/ and send errata notes to Gustavo E. Fischman fischman@asu.edu

Join EPAA's Facebook community at https://www.facebook.com/EPAAAAPE and Twitter feed@epaa_aape. 


\section{education policy analysis archives editorial board}

Editor Gustavo E. Fischman (Arizona State University)

Associate Editors: Audrey Amrein-Beardsley (Arizona State University) Rick Mintrop, (University of California, Berkeley) Jeanne M. Powers (Arizona State University)

Jessica Allen University of Colorado, Boulder

Gary Anderson New York University

Michael W. Apple University of Wisconsin, Madison

Angela Arzubiaga Arizona State University

David C. Berliner Arizona State University

Robert Bickel Marshall University

Henry Braun Boston College

Eric Camburn University of Wisconsin, Madison

Wendy C. Chi University of Colorado, Boulder

Casey Cobb University of Connecticut

Arnold Danzig Arizona State University

Antonia Darder University of Illinois, UrbanaChampaign

Linda Darling-Hammond Stanford University

Chad d'Entremont Strategies for Children

John Diamond Harvard University

Tara Donahue Learning Point Associates

Sherman Dorn Arizona State University

Christopher Joseph Frey Bowling Green State University

Melissa Lynn Freeman Adams State College

Amy Garrett Dikkers University of Minnesota

Gene V Glass Arizona State University

Ronald Glass University of California, Santa Cruz

Harvey Goldstein Bristol University

Jacob P. K. Gross Indiana University

Eric M. Haas WestEd

Kimberly Joy Howard* University of Southern California

Aimee Howley Ohio University

Craig Howley Ohio University

Steve Klees University of Maryland

Jaekyung Lee SUNY Buffalo
Christopher Lubienski University of Illinois, UrbanaChampaign

Sarah Lubienski University of Illinois, UrbanaChampaign

Samuel R. Lucas University of California, Berkeley

Maria Martinez-Coslo University of Texas, Arlington

William Mathis University of Colorado, Boulder

Tristan McCowan Institute of Education, London

Heinrich Mintrop University of California, Berkeley

Michele S. Moses University of Colorado, Boulder

Julianne Moss University of Melbourne

Sharon Nichols University of Texas, San Antonio

Noga O'Connor University of Iowa

João Paraskveva University of Massachusetts, Dartmouth

Laurence Parker University of Illinois, UrbanaChampaign

Susan L. Robertson Bristol University

John Rogers University of California, Los Angeles

A. G. Rud Purdue University

Felicia C. Sanders The Pennsylvania State University

Janelle Scott University of California, Berkeley

Kimberly Scott Arizona State University

Dorothy Shipps Baruch College/CUNY

Maria Teresa Tatto Michigan State University

Larisa Warhol University of Connecticut

Cally Waite Social Science Research Council

John Weathers University of Colorado, Colorado Springs

Kevin Welner University of Colorado, Boulder

Ed Wiley University of Colorado, Boulder

Terrence G. Wiley Arizona State University

John Willinsky Stanford University

Kyo Yamashiro University of California, Los Angeles 


\section{archivos analíticos de políticas educativas consejo editorial}

Editor: Gustavo E. Fischman (Arizona State University)

Editores. Asociados Jason Beech (Universidad de San Andrés) Alejandro Canales (UNAM) y Jesús Romero Morante (Universidad de Cantabria)

Armando Alcántara Santuario Instituto de Investigaciones sobre la Universidad y la Educación, UNAM México

Claudio Almonacid Universidad Metropolitana de Ciencias de la Educación, Chile

Pilar Arnaiz Sánchez Universidad de Murcia, España

Xavier Besalú Costa Universitat de Girona, España

Jose Joaquin Brunner Universidad Diego Portales, Chile

Damián Canales Sánchez Instituto Nacional para la Evaluación de la Educación, México

María Caridad García Universidad Católica del Norte, Chile

Raimundo Cuesta Fernández IES Fray Luis de León, España

Marco Antonio Delgado Fuentes Universidad Iberoamericana, México

Inés Dussel DIE, Mexico

Rafael Feito Alonso Universidad Complutense de Madrid. España

Pedro Flores Crespo Universidad Iberoamericana, México

Verónica García Martínez Universidad Juárez Autónoma de Tabasco, México

Francisco F. García Pérez Universidad de Sevilla, España

Edna Luna Serrano Universidad Autónoma de Baja California, México

Alma Maldonado Departamento de Investigaciones Educativas, Centro de Investigación y de Estudios Avanzados, México

Alejandro Márquez Jiménez Instituto de Investigaciones sobre la Universidad y la Educación, UNAM México

José Felipe Martínez Fernández University of California Los Angeles, USA
Fanni Muñoz Pontificia Universidad Católica de Perú

Imanol Ordorika Instituto de Investigaciones Economicas - UNAM, México

Maria Cristina Parra Sandoval Universidad de Zulia, Venezuela

Miguel A. Pereyra Universidad de Granada, España

Monica Pini Universidad Nacional de San Martín, Argentina

Paula Razquin Universidad de San Andrés

Ignacio Rivas Flores Universidad de Málaga, España

Daniel Schugurensky Arizona State University

Orlando Pulido Chaves Universidad Pedagógica Nacional, Colombia

José Gregorio Rodríguez Universidad Nacional de Colombia

Miriam Rodríguez Vargas Universidad Autónoma de Tamaulipas, México

Mario Rueda Beltrán Instituto de Investigaciones sobre la Universidad y la Educación, UNAM México

José Luis San Fabián Maroto Universidad de Oviedo, España

Yengny Marisol Silva Laya Universidad Iberoamericana, México

Aida Terrón Bañuelos Universidad de Oviedo, España

Jurjo Torres Santomé Universidad de la Coruña, España

Antoni Verger Planells University of Amsterdam, Holanda

Mario Yapu Universidad Para la Investigación Estratégica, Bolivia 


\section{arquivos analíticos de políticas educativas conselho editorial}

Editor: Gustavo E. Fischman (Arizona State University) Editores Associados: Rosa Maria Bueno Fisher e Luis A. Gandin

(Universidade Federal do Rio Grande do Sul)

Dalila Andrade de Oliveira Universidade Federal de Minas Gerais, Brasil

Paulo Carrano Universidade Federal Fluminense, Brasil

Alicia Maria Catalano de Bonamino Pontificia Universidade Católica-Rio, Brasil

Fabiana de Amorim Marcello Universidade Luterana do Brasil, Canoas, Brasil

Alexandre Fernandez Vaz Universidade Federal de Santa Catarina, Brasil

Gaudêncio Frigotto Universidade do Estado do Rio de Janeiro, Brasil

Alfredo M Gomes Universidade Federal de Pernambuco, Brasil

Petronilha Beatriz Gonçalves e Silva Universidade Federal de São Carlos, Brasil

Nadja Herman Pontificia Universidade Católica -Rio Grande do Sul, Brasil

José Machado Pais Instituto de Ciências Sociais da Universidade de Lisboa, Portugal

Wenceslao Machado de Oliveira Jr. Universidade Estadual de Campinas, Brasil
Jefferson Mainardes Universidade Estadual de Ponta Grossa, Brasil

Luciano Mendes de Faria Filho Universidade Federal de Minas Gerais, Brasil

Lia Raquel Moreira Oliveira Universidade do Minho, Portugal

Belmira Oliveira Bueno Universidade de São Paulo, Brasil

António Teodoro Universidade Lusófona, Portugal

Pia L. Wong California State University Sacramento, U.S.A

Sandra Regina Sales Universidade Federal Rural do Rio de Janeiro, Brasil

Elba Siqueira Sá Barreto Fundação Carlos Chagas, Brasil

Manuela Terrasêca Universidade do Porto, Portugal

Robert Verhine Universidade Federal da Bahia, Brasil

Antônio A. S. Zuin Universidade Federal de São Carlos, Brasil 